\title{
IoT based Smart Technology for Post-Harvest Handling in Agro Industry
}

\author{
Jaichandran $\mathrm{R}^{1}$, R. Prabha ${ }^{2}$, Karunakaran $\mathrm{A}^{3}$, S. Hemavathi ${ }^{4}$, A.Anushya ${ }^{5}$ \\ \{rjaichandran@gmail.com¹, r.praba05@gmail.com², karunakaran.a@ritchennai.edu.in ${ }^{3}$, \\ hemavathi.cse@sairam.edu.in ${ }^{4}$, anushya.alpho@gmail.com ${ }^{5}$ \} \\ ${ }^{1}$ Professor, Department of Computer Science and Engineering, Aarupadai Veedu Institute of \\ Technology, Vinayaka Missions Research Foundation (Deemed to be University), Chengalpattu, India \\ ${ }^{2}$ Associate Professor, Department of Electronics and Communication Engineering, Sri Sairam \\ Institute of Technology, Chennai, India \\ ${ }^{3}$ Assistant Professor, Department of Electronics and Communication Engineering, Rajalakshmi \\ Institute of Technology, Chennai, India \\ ${ }^{4}$ Assistant Professor, Department of Computer Science and Engineering, Sri Sairam Engineering \\ College, Chennai, India \\ ${ }^{5}$ Assistant Professor, Department of Computer Science, St. Jerome's College, Nagercoil, India
}

\begin{abstract}
The Smart innovation application is growing quickly in the agro-modern areas. The goal of this exploration was to plan and build up an ideal and versatile framework for post-reap taking care of tomatoes agro-industry. In this analysis, the Internet of Things (IoT) was added, in particular the distant detecting to anticipate the reap sum and creation limit. Prior to carrying out IoT, the viewpoint was dissected utilizing geohandling strategy. Analysis tests utilized an arbitrary network dependent on Tamilnadu. In this exploration, temperature and stickiness, and precipitation were analysis at 5 focuses. These sensors have given information routinely each day to 30 days. The outcomes showed that for 24 example points of the size of $2.5 \mathrm{~m} \times 2.5 \mathrm{~m}$, the normal gather was $8.62 \mathrm{~kg} / \mathrm{m} 2$ and the anticipated efficiency was 13.79 ton/ha. The framework could foresee precisely the collect sum and creation limit with respect to an exactness pace of $89.35 \%$. This strategy can be utilized and addresses agribusiness through advanced development utilizing shrewd agro-mechanical innovation. For future exploration, this strategy can be proceeded for post-collect taking care of utilizing Android Operating Systems..
\end{abstract}

Keywords: Smart technology, IoT, Sensors, spatial analysis, Post-harvesting, prediction.

\section{Introduction}

Right now, agrarian cropland can be chosen dependent on its territory appropriateness utilizing exactness farming (Seminar, 2016). A portion of the advances that have been created are distant detecting and Geographic Information Systems (GIS) (1). Both of these innovations give arrangements and comfort in persistent investigation with a generally wide inclusion region (2). The elaboration between far off detecting and GIS by considering a viewpoint is relied upon to introduce keen horticulture through computerized advancement. 
The all out collect expectation of agro-mechanical wares is required in arranging, dynamic, and vital arrangement for food security (3). One of wares that needs extraordinary consideration system is tomatoes (Solanum tuberosum L). It is an item that has the potential and possibilities to help enhancement for accomplishing economical food security (4). Tomatoes is the fourth biggest food agro-modern ware in Tamilnadu with is filling great in the natural temperature of 15.6 - $18.30 \mathrm{C}$, dampness of $80-90 \%$ and precipitation of 300 $\mathrm{mm} /$ month (5-9). In view of information from the Tamilnadun Central Statistics Bureau in 2019, the 5 areas with the most tomato creation are appeared in Table 1.

\section{Related Study}

The Internet of Things (IoT) stage can enhance the activity of accuracy farming (6-9). IoT can be utilized to oversee creation, and streamline crop nature of agro modern items $(10,11)$. The information is recovered by distant detecting at that point went into an AI calculation. Nonetheless, it didn't talk about the sort of sensor utilized. Data expressed that exactness horticulture upholds with IoT and food security endeavors can possibly prompt autonomous farming. Nonetheless, the investigation didn't clarify the IoT execution.

Execution assessment and use of dynamic to increase agro-modern production requires

a Decision Support System (DSS) (12-16). An IoT-based DSS has been created. In their exploration, temperature, and environment information were gathered utilizing the IoT. They utilized the IoT Node MCU stage, the DHT11 mugginess sensor, and a temperature sensor. Other exploration identified with shrewd farming has been led by Kiani and Seyyedabbasi (2018). The primary target of their exploration was to decrease water consumption while expanding rural profitability. In any case, this investigation didn't talk about analysis in the agro-business.

\section{Research Methods}

In this analysis, a computerized guide of the area organizes $(\mathrm{X}, \mathrm{Y})$ is handled. The layer stacking result and mathematical pictures decide cropland appropriateness. The spans utilized were 5 classes

\section{Boundary for research study}

Temperature, Mositure, and Rainfall

\section{Research analysis Framework}

Information assortment utilizing SHT15 temperature and moistness sensor with a solitary chip of an adjusted advanced yield (exactness $\pm 0,4 @ 5-40^{\circ} \mathrm{C}$ ) with a $2.5 \mathrm{~V}$ force supply. The sensor will send information in *.dat expansion structure each 60 minutes. The information was handled from the sensor into a temperature, stickiness, and precipitation map. Subsequent to deciding the most appropriate arrange area, at that point the aggregate reap forecast is prepared. This cycle requires information on the current absolute reap from each facilitate focuses, drone readiness, picture handling, and picture procurement. The forecast results were at that point contrasted and the current yields. 
The structural framework was planned into 2 primary exercises, specifically cropland appropriateness, and aggregate gather expectation. The structural framework in

anticipating absolute reap with IoT.

\section{Information Collection and Analysis}

Information were gathered from 5 areas in Dharmapuri, Salem, Krishnagiri, Dindigul, and Coimbatore (Tamilnadu) to decide a fitting exploration test. This analysis chose dependent on the biggest number of creations. The point of view was dissected utilizing analysis.

\section{Examination variable}

The effect of environmental change on cropland reasonableness is vital to economical agribusiness (Worqlul et al. 2019). In view of their examination, Peter and Messina (2020) proposed the variables that influence cropland appropriateness are temperature and precipitation. In expansion, Tesfay et al. (2017) found the slant profile, soil type, and dampness are additionally significant factor of cropland appropriateness.

\section{Results And Discussion}

Spatial analysis of data reveal the exact prediction of product production from 5 districts in Dharmapuri, Salem, Krishnagiri, Dindigul, and Coimbatore (Tamilnadu). This study selected based on the largest number of tomato product productions.

Parameters like temperature, humidity, and rainfall are varies with district along with their yield. The higher temperature causes loss in production where lower temperature cause minimal yield during production. Optial temperature were noted with higher yield throught year. Similarly humidity and rainfaill also plays significant roles in production (Table 1 and Figure 1)

Table 1. Value of temperature, humidity, and rainfall (2018-2019)

\begin{tabular}{|l|l|l|l|l|l|l|}
\hline \multirow{2}{*}{$\begin{array}{l}\text { Sample } \\
\text { code }\end{array}$} & \multicolumn{2}{|l|}{ Temperature } & \multicolumn{1}{l|}{ Humidity } & Rainfall \\
\cline { 2 - 7 } & OC & Value & Percentage & Value & mm/ Yearly & Value \\
\hline S1 & 34 & 4 & $65-70$ & 4 & 60.00 & 5 \\
\hline S2 & 32 & 3 & $70-75$ & 4 & 86.83 & 5 \\
\hline S3 & 31 & 3 & $75-80$ & 3 & 91.92 & 4 \\
\hline S4 & 30 & 2 & $70-80$ & 3 & 97.08 & 4 \\
\hline S5 & 28 & 2 & $85-90$ & 2 & 117.75 & 2 \\
\hline
\end{tabular}


Figure 1. Temperature, Humidity and Rainfall (2019-2020)

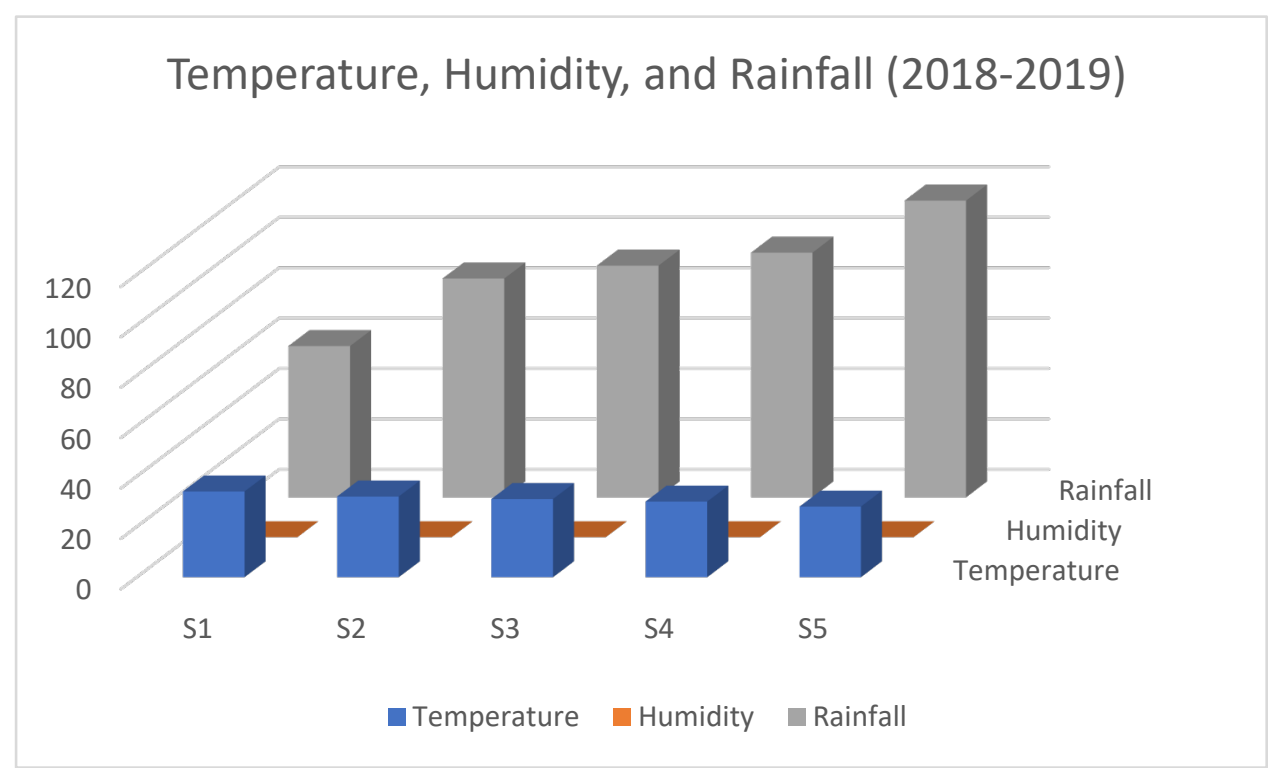

Parameters like temperature, humidity, and rainfall are varies with district along with their yield. The higher temperature causes loss in production where lower temperature cause minimal yield during production. Optial temperature were noted with higher yield throught year. Similarly humidity and rainfaill also plays significant roles in production (Table 2 and Figure 2)

Table 2. Value of temperature, humidity, and rainfall (2019-2020)

\begin{tabular}{|c|c|c|c|c|c|c|}
\hline \multirow{2}{*}{$\begin{array}{l}\text { Sample } \\
\text { code }\end{array}$} & \multicolumn{2}{|c|}{ Temperature } & \multicolumn{2}{|l|}{ Humidity } & \multicolumn{2}{|l|}{ Rainfall } \\
\hline & OC & Value & Percentage & Value & $\mathrm{mm} /$ Yearly & Value \\
\hline S1 & 35 & 4 & $65-70$ & 4 & 62.00 & 5 \\
\hline S2 & 32 & 3 & $75-75$ & 4 & 87.83 & 5 \\
\hline S3 & 31 & 3 & $70-80$ & 3 & 92.92 & 4 \\
\hline S4 & 31 & 2 & $75-80$ & 3 & 97.08 & 4 \\
\hline S5 & 29 & 2 & $85-90$ & 2 & 118.75 & 2 \\
\hline
\end{tabular}


Figure 2. Temperature, Humidity and Rainfall (2019-2020)

Temperature, Humidity, and Rainfall (2019-2020)

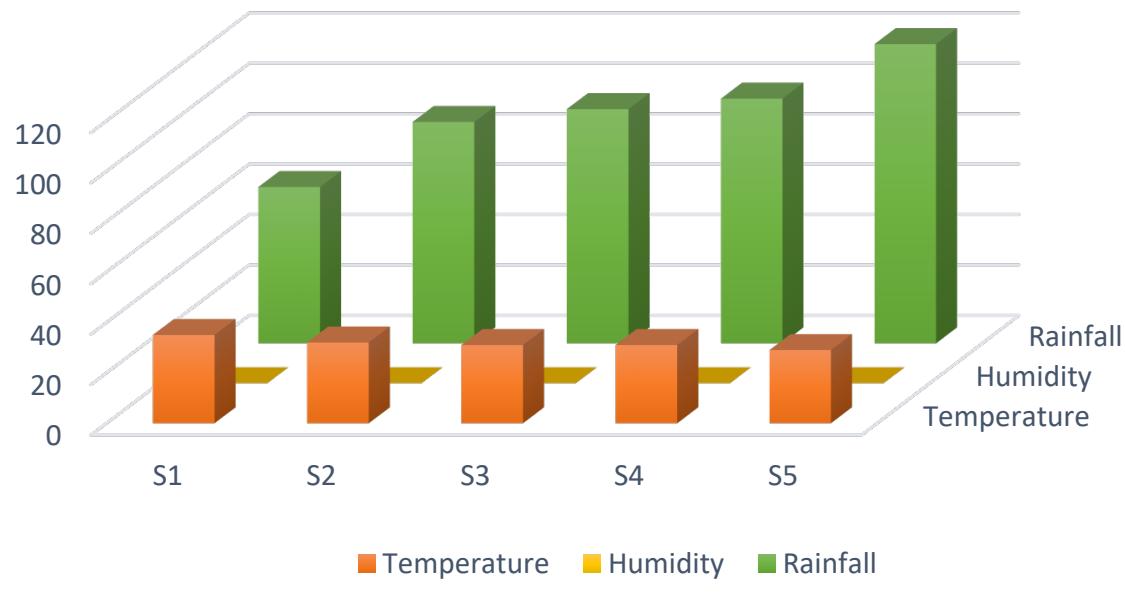

Predicton of yield in various district using IoT based sensor and grid helps farmer do farming according with different plant varieties. Here comparison made between 2018- 2019 and 2019-2020 which reveals the productivity prediction with harvest area and also total productions.

\begin{tabular}{|l|l|l|}
\multicolumn{2}{l}{ Table 3. The total harvest comparison (2018-2019) } \\
\hline Comparison & Existing condition & Prediction of the total harvest \\
\hline $\begin{array}{l}\text { Production } \\
\text { (tons) }\end{array}$ & $7,87,180$ & 16.62 \\
\hline Harvested Area (Ha) & 27,008 & 0.63 \\
\hline $\begin{array}{l}\text { Productivity } \\
\text { (m.tons/Ha) }\end{array}$ & 29.51 & 24.89 \\
\hline
\end{tabular}

Table 4. The total harvest comparison (2019-2020)

\begin{tabular}{|l|l|l|}
\hline Comparison & Existing condition & Prediction of the total harvest \\
\hline $\begin{array}{l}\text { Production } \\
\text { (tons) }\end{array}$ & $8,87,080$ & 8.62 \\
\hline Harvested Area (Ha) & 29,078 & 0.63 \\
\hline $\begin{array}{l}\text { Productivity } \\
\text { (m.tons/Ha) }\end{array}$ & 30.51 & 13.79 \\
\hline
\end{tabular}


Figure 3. Total Harvet Comparison

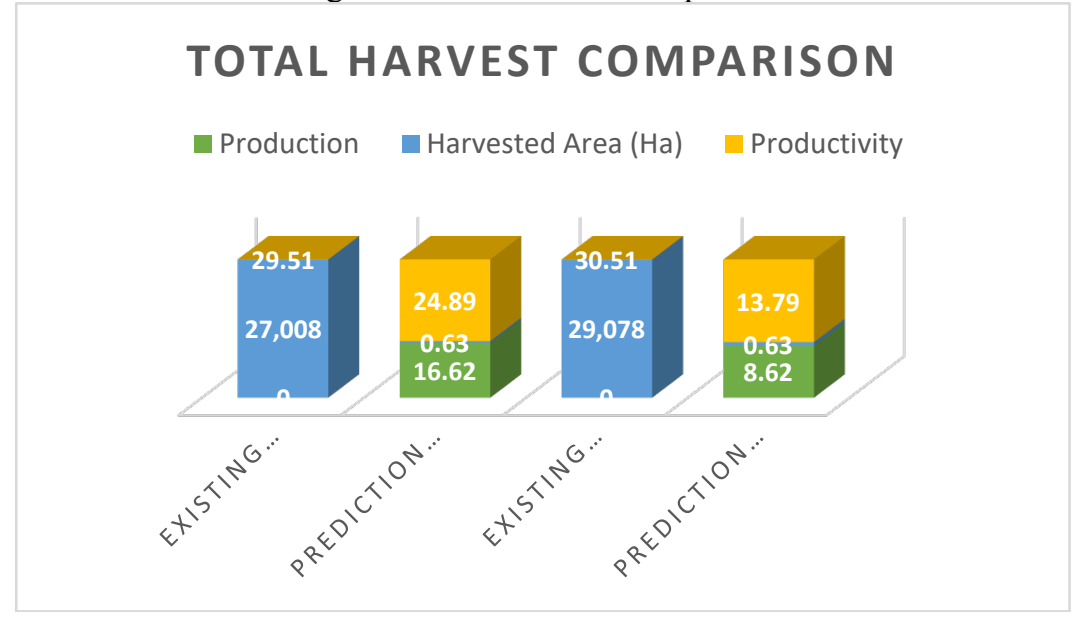

The partition of locales utilizing multi-thresholding was then shown in the division results. Where district 1 is the foundation picture, and locale 2 was the potato leaf picture. In the wake of handling the pixel rate information for every district, the collect examples were gauged. The normal example weight was $8.62 \mathrm{~kg}$ or has profitability of $1.38 \mathrm{~kg} / \mathrm{m} 2(13.79$ tons/ha)

\section{Conclusion}

In view of 5 example focuses with a normal zone of $2.5 \mathrm{~m} \times 2.5 \mathrm{~m}$, the normal all out gather was $8.62 \mathrm{~kg}$ per $\mathrm{m} 2$. A correlation of existing conditions with expectations utilizing IoT and examination can be found in Table 3 and 4.

The Web Ontology Language (WOL) design in the semantic web utilizing - transient factors, just as introduction and collection strategies on measurements, can additionally improve the exactness of forecasts (13-17). Keen System joined with DSS can foresee all the more precisely collect time, holding up time, and ideal course assurance in the agro-modern area (6-9). The exactness got in this examination, as indicated by Dewi and Muslikh (2013), is acceptable since it was higher than $80 \%$. This exploration has affirmed that an IoT based keen agro-mechanical innovation and examination can anticipate collect volume and efficiency with a superior exactness rate (17-22).

\section{References}

[1] Antony AP, Leith K, Jolley C, Lu J, Sweeney DJ. 2020. A review of practice andimplementation of the internet of things (IoT) for smallholder agriculture. Sustainability. 12(9):1-19. 
[2] Araby AA, AbdElhameedMM, Magdy NM, Said LA, Abdelaal N, Abd Allah YT, DarweeshMS, Fahim MA, MostafaH. 2019. Smart IoT Monitoring System for Agriculture with Predictive Analysis. Proceedings of 8th International Conference on Modern Circuits and Systems Technologies, Thessaloniki, Greece. 13-15 May 2019.

[3] Backhausen JE, Klein M, Klocke M, Jung S, ScheibeR. 2005. Salt tolerance of potato (SolanumtuberosumL .var . Desire) plants depends on light intensity and air humidity. Plant Science. 169(1): 229-237.

[4] Dewi C and MuslikhM. 2013.PerbandinganAkurasiBackpropagation Neural NetworkdanANFIS Untuk Memprediksi Cuaca. Journal of Scientific Modeling\& Computation.1(1):713. FoughaliK, Fathallah K, and Frihida A.2019.A Cloud-iot based decision supportsystemfor potato. Procedia Computer Science.160(1):616-623.

[5] Foughali K, Fathallah K, and Frihida A. 2018. Using Cloud IOT for disease prevention in precision agriculture. Procedia Computer Science. 130(1): 575-582.

[6] HouX, Li R, He W, Ma K. 2020. Effects of planting density on potato growth, yield, and water use efficiency during years with variablerainfall on the Loess Plateau, China. Agricultural Water Management. 230(11): 1-9.

[7] Kardiyono, Marimin, Indastri NS, Yuliasih I, Pramuhadi G. 2018 . Strategipeningkatanproduktivitasdankualitaskedelailokaldenganpendekatanproduktivitashijau. JurnalTeknologiIndustriPertanian. 28(3): 342-353.

[8] Kiani F and Seyyedabbasi A. 2018. Wireless sensor network and Internet of Things in precision agriculture. International Journal of Advanced Computer Science and Applications. 9(6): 99-103.

[9] Kuyu CG, Tola YB, and Abdi GG. 2019. Study on post-harvest quantitative and qualitative losses of potato tubers from two different road access districts of Jimma zone, South West Ethiopia. Heliyon. 5(7): 1-7.

[10] Liu W, Huang Y, Ye Z, Cai W, Yang S, Cheng X. 2020. Renyi's Entropy Based Multilevel Thresholding Using a Novel Meta-Heuristics Algorithm. Applied Sciences. 10(1): 1-18.

[11] MarcuI,VoicuC,DragulinescuAMC,FratuO,Suciu G, Balaceanu C, Andronache MM. 2019. Overview of IoT basic platforms for precision agriculture. Lecture Notes of the Institute for Computer Sciences, Social-Informatics and Telecommunications Engineering. 283(3):124- 137.

[12] NellisMD,PriceKP,andRundquistD.2008.Remote Sensing of Cropland Agriculture. In The SAGE Handbook of Remote Sensing. University of Nebraska - Lincoln. pp.368-383.

[13] Peter BG and Messina JP. 2020. Crop climate suitability mapping on the cloud: a geovisualization application for sustainable agriculture. Scientific Reports:1-17.

[14] Rad C-R, Hancu O, Takacs I-A, Olteanu G. 2015. Smart Monitoring of Potato Crop: A CyberPhysical System Architecture Model in the Field of Precision Agriculture. Agriculture and Agricultural Science Procedia. 6(1): 73-79.

[15] Raja S, Govindakrishnan P, and Chakrabarti S. 2020. A Review: A Framework for Yield Improvement in Kharif/Rainy Season Potato in the Low Land Tropics. Acta Horticulturae et Regiotecturae. 23(1): 44-55.

[16] Rykaczewska K. 2017. Impact of heat and drought stresses on size and quality of the potato yield. Plant Soil Environment. 63(1): 40-46.

[17] Sugiharyanto S. 2017. Prospek Pengembangan Budidaya Tanaman Kentang di Indonesia. Geomedia: Majalah Ilmiah dan Informasi Kegeografian. 6(2): 43-52.

[18] Tervonen J. 2018. Experiment of the quality control of vegetable storage based on the Internet-ofThings. Procedia Computer Science. 130: 440-447.

[19] Tesfay T, Biedemariam M, Hagazi M, Hailu TG. 2017. Land Capability and Suitability Evaluation for Rain-fed Crops in Semi-arid Lowland Area of North. An International Journal of Plant Research. 30(3): 1-5.

[20] Voss RE, Baghott KG, and Timm H. 2004. Proper Environment for Potato Storage. Vegetable Research and Information Center. 3(1): 1-3.

[21] Wang Y, Naber MR, and Crosby TW. 2020. Effects of wound-healing management on potato postharvest storability. Agronomy. 10(4): 1-17. 
